\title{
On improving the historic manufacture territories in the mining cities of the Middle Urals
}

\author{
Margarita Kolchina, Vladimir Konovalov, and Natalya Kolchina \\ Ural State Mining University, 620144, Kuibyshev st., 30, Ekaterinburg, Russia
}

\begin{abstract}
The article is devoted to the analysis of spatial organization of the mining cities historical sites located in the Middle Urals with a special focus on the old mining territories. The article overviews the Demidov family contribution in the mining development of the Ural Region; the presented research also suggests a mining cities classification in terms of their age; the given study analyses the land management and construction development of the historic sites and its residential areas, and the condition of the architectural objects which form these sites and areas; the authors of article propose a classification of historical sites. The research singles out the ecological, social and economic problems resulting from the still existing out-dated mining sites. The authors recommend a concept of revitalizing the historic mining territories. The article also determines the trends for further research.
\end{abstract}

\section{Introduction}

With the beginning of the post-industrial era in the developed countries of Europe, a large movement has commenced towards the industrial heritage preservation. It is considered to be an important element of tangible culture of the humanity. The industrial heritage of the leading European countries is thoroughly categorized, studied, and turned into museums and promoted.

Old ore mines, coal mines, plants and factories, dams, canals and many other manufacture sites are regularly visited by thousands of tourists not only from Russia, but also from around the globe. In Russia, a great deal of attention is given to the preservation and popularization of the cultural heritage. A large number of historical and cultural sanctuaries has been created; a wide range of scientific and popular books have been published on the topic; however, insignificant actions were taken to restore the historic manufacture territories and to preserve the manufacturing legacy of the industrial area of the country - the Urals.

The research goal is to overview the possibilities of reviving the historic manufacture territories of the old cities of the Middle Urals.

Aims:

- to analyze the land management and construction development of the mining cities in the Middle Urals; 
- to subdivide historic sites into categories of land management and construction development;

- to single out the problems faced by the mining cities;

- to suggest a set of measure in revitalizing the historic mining territories based on a complex approach with the goal of preserving the uniqueness, authenticity, originality and historical resources of the urban environment.

The active process of developing the Ural Region was launched in the beginning of the 18 th century and it is connected with the construction of mining and metallurgic factories. In fact, Russia being perceived as one of the richest countries in the world in terms of its mineral resources is only true when looking back at the last few centuries. A great contribution in the manufacture development in the Ural Region was made by the Demidov Dynasty. The history of Ural Region factories is a result of a first successful wave of industrialization in Russia. Constructing and improving their own manufacturing sites, the Demidov family founded cities, developed the infrastructure, constructed roads, populated the previously uninhabited areas of the Ural Region.

It had been mentioned earlier that the metallurgic factory with its ore mines and fertile land property, including dams, water basins, disposal areas and countries houses served as the initial territory for establishing mining cities. Next to these cities, townships were built, which served as the residential areas for the mining factories workers and their families. This method remained as the key method for a long time-period and manifested itself strongly at the end of the 1950's when new mining cities began to emerge.

\section{Materials and methods}

\subsection{Urban territories revitalization}

Revitalization (> Lat. 're-' - 'resume' and 'vita' - 'life', lit.: the return of life) in the context of urban studies is a process of reproducing and reviving the urban environment [2].

Urban environment revitalization also implies the "reviving" of the urban territory or object which is no longer functioning; and creating an active, vital environment out of the "dead" urban environment [3]. Revitalization is also regarded as a transformation of the urban environment towards a more convenient and interesting human-friendly environment.

Numerous information sources and scholars in their earlier studies claim that the key principle of revitalization lies in the discovery of prospective possibilities of the outdated methods while taking into account their modern functions.

Revitalization has the following aims:

- urban environment socialization and active engagement;

- ecological problems elimination;

- infrastructure components development, which would promote tourism and scientific research activities;

- and investment promotion as a result [2].

Revitalization initially emerged in developed countries in the second half of the 19th century. The idea of reviving the urban environment was originally introduced in the 19th century England as a counteraction to the limited and insanitary environmental conditions. The Doctrine was designed to improve the social, economic and living conditions in a particular city. At the same time-period, the necessity for revitalization occurred in France [4]. 


\subsection{Revitalization of urban manufacturing territories}

In the modern-day world, the revitalization of manufacture complexes located withing the urban boundaries has become a very popular trend. Turning towards this method is guided by the discrepancies between the social demands (especially in terms of environmental friendliness, esthetics, and land management) and the existing manufactures construction development. In this case, revitalization is understood as "the reconstruction of manufacturing sites architecture and modification of its functions" [2].

This issue became prominent starting from the middle of the 20th century, however, it is critically important today.

"Industrial heritage is a vulnerable and an insignificantly evaluated aspect of heritage" suggests the Margarita Stieglitz, the Professor of the St.- Petersburg Stieglitz Academy. The scholar believes that "...the historic manufacturing sites architecture and engineering ingenuity have a significant status, just like any other form of heritage. They should be protected and included in the designated registry". Meanwhile, Stieglitz adds that: "a new stage has begun - the incorporation and shaping the objects in such ways, which would not 'destroy' the architecture heritage, but, on the contrary, transform it into an impulse of urban environment development" [5].

The Agency for strategic development "Center" (Moscow) presented the research results devoted to the typology of manufacturing territories and the practical experience in redeveloping based on the result of revitalizing the Moscow city manufacturing territories. The research covered 46 manufacturing sites. The agency carried out an architectural, cityplanning, historical and cultural as well as economic analysis. The key research stages included the categorization of the manufacture sites and evaluation of their future potential. As a result, two main approaches were selected as the most applicable in working with the industrial heritage: adaptation and reconstruction [5].

The concept of manufacturing areas revitalization means a transition from the initial function and image of the manufacturing process. The concept also presupposes the following: the half-destroyed and abandoned manufacture sites are given "a new life", they are assigned a new meaning and function, meanwhile, they improve the urban landscape [6]. Further are given some examples of reviving the manufacturing areas worldwide.

The Duisburg-Nord Landscape Park is a park located in the German city of Duisburg, which was established in 1994 on the territory of Meiderich Hutte, a restricted metallurgic factory (established in 1901). The total area of the park covers 228 ha. When the factory was closed in 1985, the government wanted to demolish it, however, the local activist group suggested to create a landscape and industrial park in its place and their idea was supported. Blast furnace No. 5 was transformed into an observation platform for visitors.

The former Manufactura manufacturing factory in Lodz, Poland. After the manufacturing process was completed, the Manufactura manufacturing factory became the largest trading and entertainment center not only in Poland, but also in all of Central Europe. Owing to the process of revitalization and an appropriate representation of the former manufacture complex, Lodz became one of the most popular touristic cities in Poland.

In 1896-1899, gas holders were built (62 $\mathrm{m}$ in diameter and $72 \mathrm{~m}$ high), which served as gas reservoirs, however, in 1970, they were no longer practical. In 1995, a decision was made on transforming the gas holders' functions and placing them in the household and business and commercial facilities.

The Kalinin Crystal and Glass-Producing Factory (Moscow) was constructed in the first half of the 20th century. In the middle of 2009, a decision was made to revitalize (revive) the architectural object under a new brand: the Flacon Design Factory; the key mission of this new factory is establish a creative cluster in design and other creative industries. A new infrastructure was created and improved; a development strategy was outlined. 
The New Holland (St.-Petersburg) is a man-made island in the delta of the Neva River. In different time-periods, this location was a storage area for ship-building timber, a naval jail, a smithery, and a basin for conducting experiments. In 2014, the Dutch company West 8 designed a project on the restoration and reorganization of the island. Today, it is a popular recreational area for the local people and tourists.

Nimloft (Ivanovo). The idea of creating a museum was initiated in the summer of 2011 and the project was completed in 2014. The Nimflot museum territory is subdivided into two zones: social events zone, where expositions, festivals, sports events are held; and a permanent exposition which has a collection of unique wall paintings.

The research works by S.V. Kornienko (Professor of the Volgograd State Technical University, Russia) are devoted to the revitalization of depressive manufacture sites. The scholar proposes a model of transforming manufacturing areas and creating technological parks in place of the former manufacturing sites [7].

Experts of the Vladimir State University, Russia note that the issue of revitalization in the city centers of the Ural Region, western and eastern regions of Siberia is directly connected with the future destiny of a given factory in the urban landscape. In their article, the scholars suggest to provide the manufacturing areas with the following:

- "creative clusters;

- business parks and business centers;

- luxurious and residential [8].

All of the reviewed options can partially be applied in the process of restoring historic manufacturing sites of the old mining cities of the Ural Region. First, architectural objects under study are buildings and constructions which were constructed in the 19th-the beginning of the 20th centuries and they remain in a relatively decent technical condition. Second, the features of the architectural objects located on the premises of the mining factories were not taken into account. Among these architectural objects, there is a predominating amount of technological facilities. Third, the facilities listed above do not maintain the same historic value as the Ural Demidov factories, which were constructed in the first half of the 18th century.

\subsection{On the preservation of the mining heritage}

Perhaps, the issues discussed in the research works conducted by Professor Juergen Kretschmann (Technische Hochschule Georg Agricola University, Bochum, Germany). In his article "Postmining aimed at sustainable development in Germany", the scholar states that "the mining industry caused a great impact on the social, economic, and ecological development of many regions by changing the landscapes, cities and the population structure"; he adds that "the heritage which was constructed is one of the most unique cultural artefacts of the modern society and people must strive to preserve, develop and present these artefacts, especially architectural mining objects as a separate and significant contribution into the sustainable development of a particular mining region". The research materials on the issue of mining heritage and preservation of the unique architectural sites in Germany, the incorporation of dead mining pits are published in the world-leading research journals [9, 10]. These research materials are largely devoted to the preservation of modern mining sites.

Research materials by V.E. Konovalov, A.I. Semyachov, V.A. Pochechun [11] are devoted to the issues of reviving the mining complex sites and prospective possibilities of maintaining the mining landscapes for further usage. 


\subsection{The history of mining factories establishment in the Middle Urals}

The Ural region was developed rapidly. Only the fact that the first (Nevyansky) factory was given to Nikita Demidov by the tsar Peter the First in 1702 serves as a strong starting point; in 1703, the factory manufactured its products. By 1727, The Demidov family have built six factories: the Shuralinsk factory (1716-1890), the Byngovsk factory (1718), the Viysk copper-smelting factory (1722-1918), the Nizhny Tagil factory, the Nizhylaisk factory (1723-1909), the Verkhny Tagil (1718-1917) (Fig.1); all of these factories were designed for iron-smelting purposes.

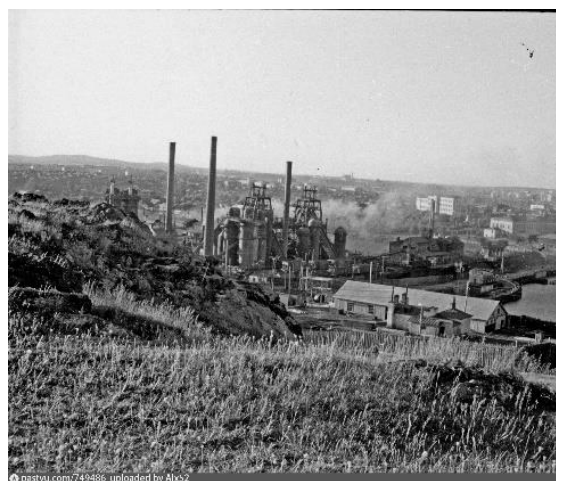

The Nizhny Tagil factory
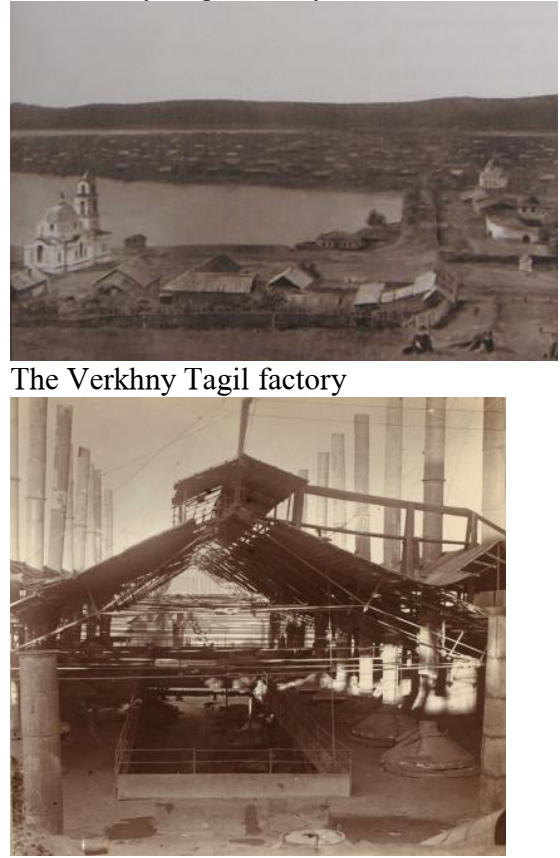

The Viysk Copper-Smelting factory

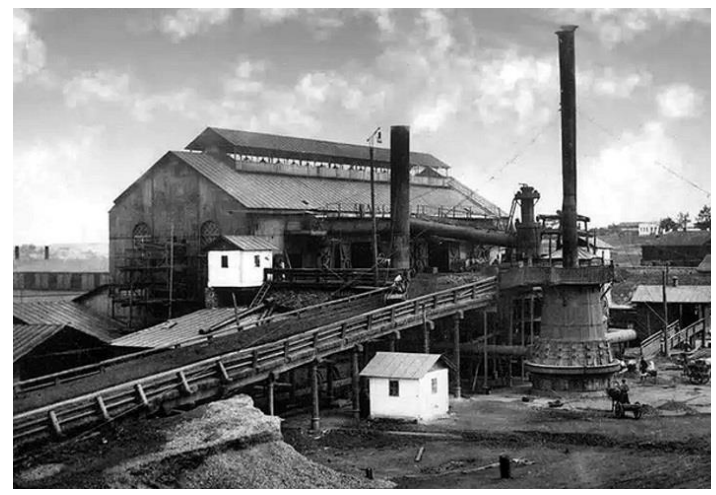

The Nizhny Tagil factory (early 20th century)

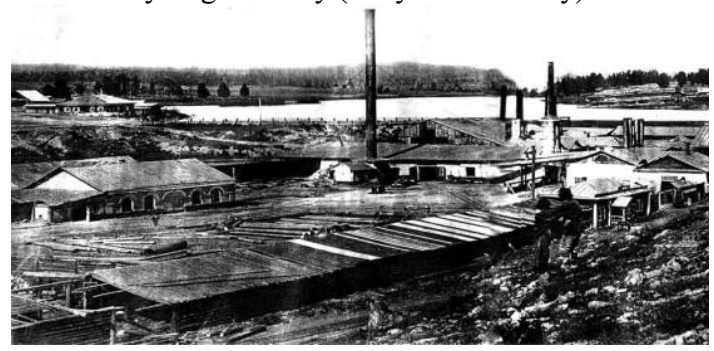

The Nizhnelaisk factory

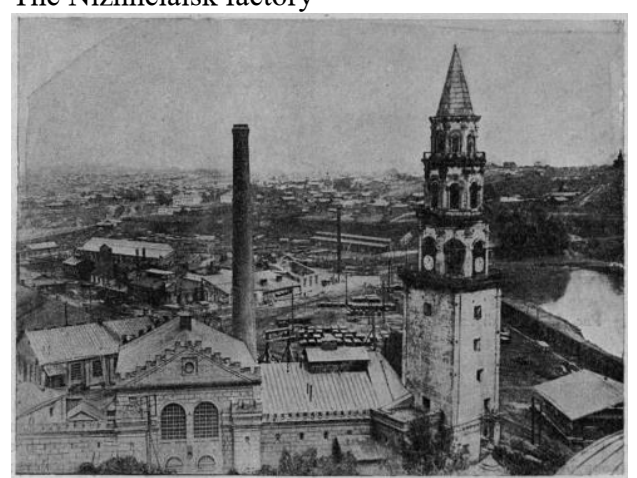

The Nevyansk factory

Fig. 1. Pictures of the old Demidov factories

Thus, the Demidov family established a mining and smelting empire within a short timeperiod. By 1745, there were 32 Demidov factories were functioning in different areas of the Ural Region and Siberia. The Demidov family continued constructing factories in the Ural 
Region for a long period of time. Their main area of expertise was iron- and copper-smelting as well as weapon production; the mining production was actively developed to support these manufacture spheres. Figure 2 shows the boundaries of the Akinfiy Demidov establishment.

When the Demidov factories seized to function, much of the property was destroyed or otherwise gone forever. Despite that, however, some of the Demidov factories still function today; buildings, dams, and other elements of the engineering and transport infrastructure are currently used in agriculture. The cities, which were founded by the Demidov family, continue developing.

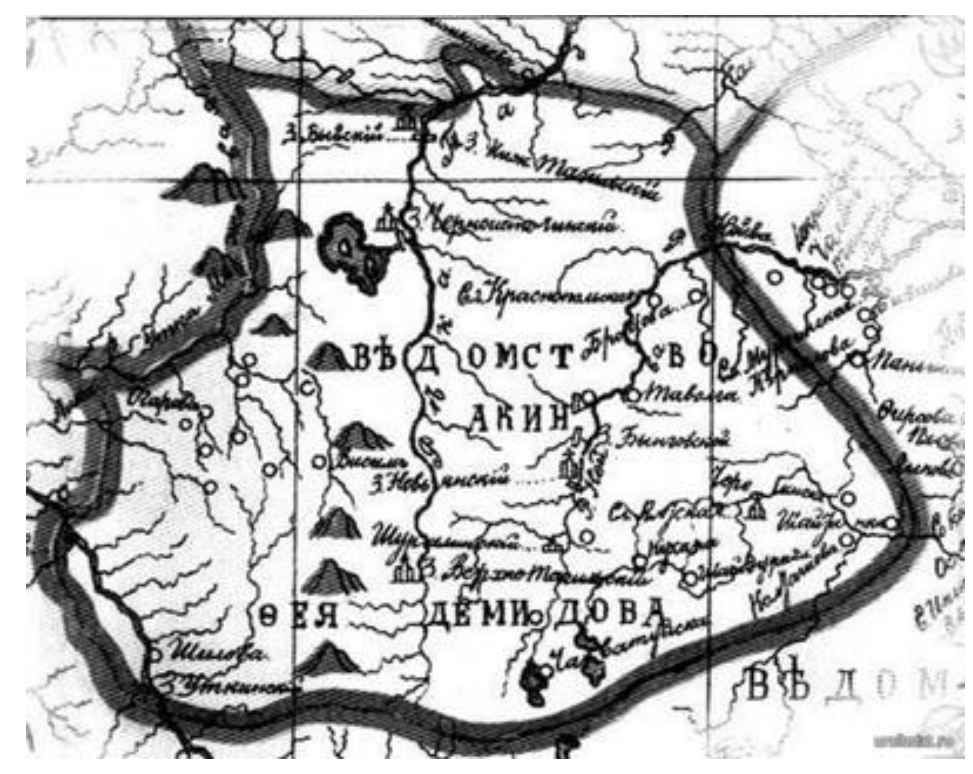

Fig. 2. A map of the Akinfiy Demidov property

\section{Results and Discussion}

\subsection{Ural Region mining cities classification}

Research has shown that today there is a great variety of cities in the Middle Urals, which were established as a result of the first wave of industrialization of the Russian Empire in the 18th century. All of these facilities are mining factories, due to the fact that their territory includes ore mines, factories, ponds, and dams. The mining industry development in the Ural Region continued in the 19th and the 20th century; there was a continuous process of constructing new coal mines, ore mines, carriers and metallurgical plants; the already existing cities continued to grow rapidly and new cities were established.

The authors suggest classifying the Ural manufacturing cities in terms of their age and, thus, to single out three main groups:

a) old cities (over 300 years old, which emerged in the 18th century or earlier);

b) average-age cities (which emerged in the 19th-the beginning of the 20th century);

c) newly (-built cities in the 20th century).

Old mining cities (MCs) differ from all the others: apart from the modern manufacturing facilities, these cities contain old closed down or active factories, new residential areas as well as social and business centers, which co-exist together with the historic construction development. 
Despite this, any old city has historical sites in which there are old architectural sites and landscapes. These territories are the starting point of a residential area. Depending on the origin and functions of a particular township, there is a prevailing type of a specific construction development style. For instance, strongholds of Christianity include a great number of churches (the Verkhoturye area), former fortresses - fortification buildings (Turinsk), trading squares, banks, shops and rows of shops in one building (Irbit), mining facilities - ore mines, factories, small business offices, educational institutions, hospitals, etc. All the historical sites had churches, cathedrals, and monasteries.

\subsection{Historical sites classification of the old mining cities}

The analysis of land management and historical sites construction development of the old MCs showed a necessity in classifying them in terms of their functional implementation and the type of construction development.

In the course of the study, it was determined that historical centers of Ural cities contain the following:

- strictly localized territories which were created either by hieratic architectural sites (Solikamsk, Permsky Krai), or by social and business facilities, or by manufacturing facilities;

- territories comprising of hieratic, social and residential facilities;

- territories created together with the civil, hieratic and manufacturing facilities (Ekaterinburg, Sverdlovsk region).

The authors suggest to single out the following (Fig. 3):

a) monofunctional (local) historical sites;

b) residential historical sites which include hieratic, social and residential facilities;

c) multifunctional historical sites which include the civil, hieratic, and manufacturing sites.

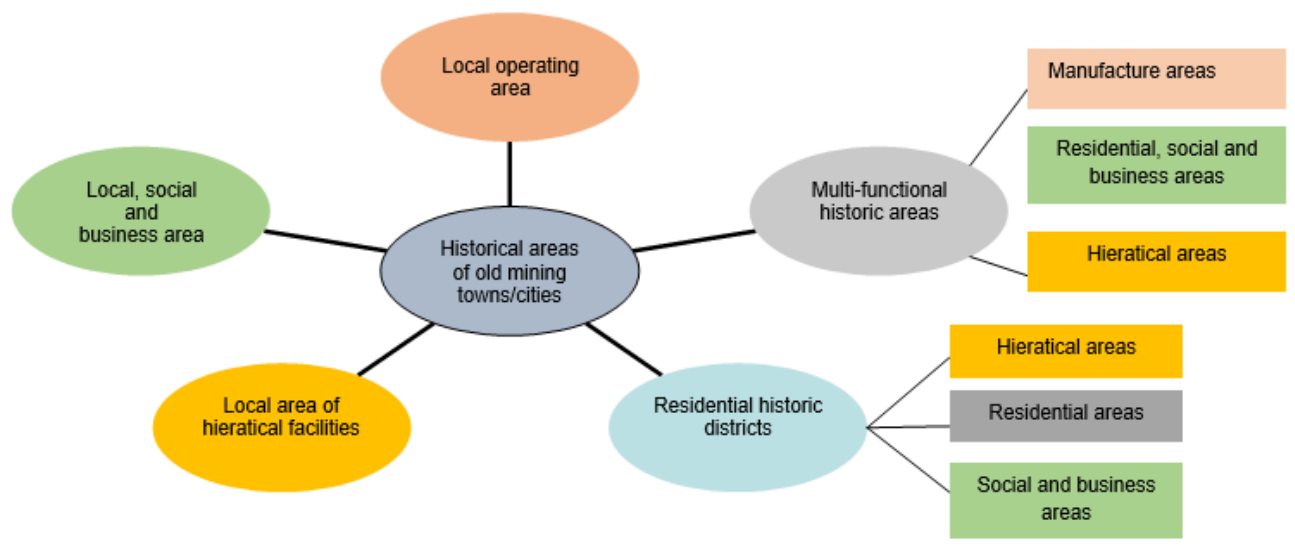

Fig. 3. The historical centers structure in old cities

Residential historical sites comprising of old residential, social and business as well as hieratic buildings are an integral part of any city established 150 years ago or even earlier. Buildings, which were constructed in the first century of residential areas existence as a concept, form the historical basis of the historically-developed centers. 
Multifunctional historical sites emerged as a result of territorial development of the mining townships; this was accomplished by conquering the nearby territories. As a result, ore mines, factories, and dams became a part of the residential areas; today, they are an essential component of the historical center.

The architectural objects, which occurred in various time-periods, differ in their further fate and technical condition:

- architectural objects which are completely destroyed;

- architectural objects which are half-destroyed;

- architectural objects which still remain but they are abandoned;

- preserved and functioning architectural objects.

Historic buildings, constructions and complexes, which are enlisted as cultural heritage architectural objects (CHO) and they have a consistent trend of being restored and preserved. This is required by the Russian legislative system. Today, the focus has been shifted towards the Russian provincial areas. i.e., the historical centers of small-sized and average-sized cities of the Ural Region. As a rule, CHOs are restoration is budget-funded in accordance with their status. Hieratic architectural objects, which were returned to the eparchy by the government, are revived using the charity funds and church members' donations.

Thus, historical residential sites of the Ural cities are being renewed, revived and they are becoming places for tourist attraction, tourism, and small businesses.

Old mining cities normally contain historical mining sites (HMS); this is what makes the Ural settlements different from the majority of others. Unlike the residential and multifunctional historical sites, historically established HMSs, in which the manufacturing and engineering architectural objects are located dating back to different time-periods in history, have remained abandoned and polluted for an extensive period of time. An example of such phenomena are the following factories: Shaytansk, Revdinsk, Bilimbaevsk, Nizhnesaldisk, Sysertsk, Staroutkinsk, Bisertsk, Alapaevsk factories, etc [12]. There is no existing data on these factories in the the Unified State Register of Cultural Heritage Objects (USRCHO) and in the List of Historical and Cultural Sites of the Sverdlovsk Region; this is one of the key reasons for the monuments destruction in the Russian industrial sphere. Figure 4 shows the deteriorating Kuvshinsk agglofactory and the Barachikhensk factories.

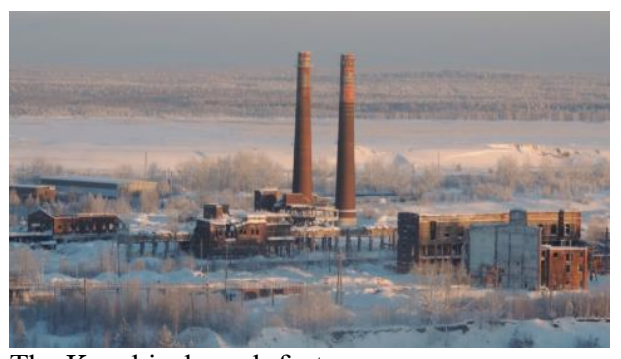

The Kuvshinsk agglofactory

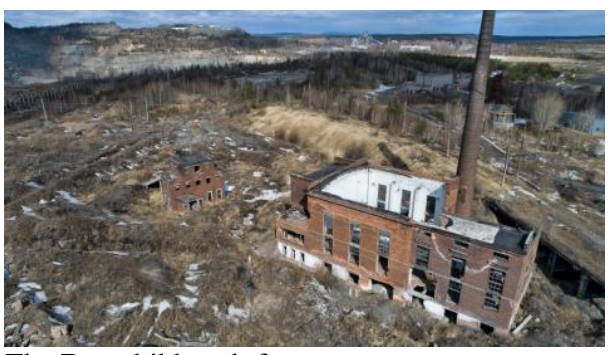

The Barachikhensk factory

Fig. 4. Abandoned manufacture sites

The existing situation provokes at least three issues:

- economic - ineffective incorporation of urban land management;

- ecological;

- social, aesthetic and safety issues.

\subsection{The concept of revitalizing historical mining sites}


The authors propose a concept of revitalizing the historical mining sites in the old mining cities of the Middle Urals; this concept will not only allow preserving the unique heritage of the Ural industrial areas, but also reviving these territories and increasing their (social and economic) value and status.

The concept includes the following stages:

1) carrying out a large-scale inventory reconciliation of the old manufacturing sites, which includes: singling out these sites, including them in the register, describing and evaluating their technical condition.

2) carrying out technological expertise tests of the functioning old factories and considering the necessity for their further exploitation or closure.

3) defining the limits for historical manufacturing territories, enlisting them in the Unified State Register of Immovable Property (USRIP), the State Information System of Urban Construction (SISUC), the general urban plans, the Land Management and Construction Development Guidelines in the corresponding municipal areas;

4) defining the status of the historic architectural objects which are registered as cultural heritage objects (CHOs), municipal, regional, and federal; securing the responsibility for the restoration and preservation of these objects under the mentorship of the corresponding state administration.

4) registering and documenting the $\mathrm{CHOs}$ in and their conservation areas in the state information resources: the Unified State Register of Cultural Heritage Objects (USRCHO), the Unified State Register of Immovable Property (USRIP), the State Information System of Urban Construction (SISUC);

5) developing programs and projects on the revival (restoration and reconstruction) of the historical manufacturing objects and creating museum complexes;

6) searching for investors and budget funds for implementing the programs and projects;

7) designing a plan of actions to control the implementation of the and projects;

8 ) organizing scheduled observations on the condition of the manufacture sites heritage.

The following should serve as the foundation for revitalization projects:

- measures aimed at reviving (restoring), modernizing, reconstructing the old manufacturing factories and sites;

- series of actions on the beautification of the territories;

- creating museum complexes and tourism infrastructures, including observation platforms. recreational areas, trading areas, catering areas, etc.;

- developing a transport infrastructure which would provide vehicle access to the sites, connect the museum complexes together and link them to the historical and social cities centers.

Some experience in singling out old manufacture sites was obtained in the Sverdlovsk Region. Historians, geographers, and regional studies experts have made the greatest contribution in the study of the manufacturing heritage in the Sverdlovsk Region. In 1993, a travel tour was held on the study and preservation of the Urals industrial heritage [13]. In June 2009, in partnership with the Institute of History and Archeology, Ural Branch of RAS (IHA UB RAS), historians, regional studies experts accomplished another large-scale expedition covering the territories of the Sverdlovsk and Chelyabinsk regions. As a result, 25 former and existing factories were observed; the scholars located the functioning factories, closed factories and abandoned factories as well as restored factories and plants.

Scholars also have some first-hand experience in reviving the old facilities. An example of this is the Nizhny Tagil metallurgic factory (Fig. 5) which was founded by the Demidov family in the 18th century and continued to function until 1987. In 1989, a unique open-air Museum of Mining History of the Middle Urals was created in its place. This idea was supported by the regional government and, in 1998, E.E. Rossel, the governor of the Sverdlovsk Region issued a decree "On the urgent measures in preserving the industrial, 
cultural and historic heritage of the Sverdlovsk Region", in which he ordered: 1) to allow the Nizhny Tagil local government to act on its own terms and to create the open-air Museum of Mining History of the Middle Urals in order to preserve the industrial heritage of the Ural Region; 2) to develop a plan on creating a National Mining History Park of the Middle Urals. The result of these measures was the interdisciplinary monograph research project "National Mining Park of the Middle Urals" devoted to the issue of detecting, preserving and incorporating the rich industrial, historical and cultural heritage on a large social scale [14, $15]$.

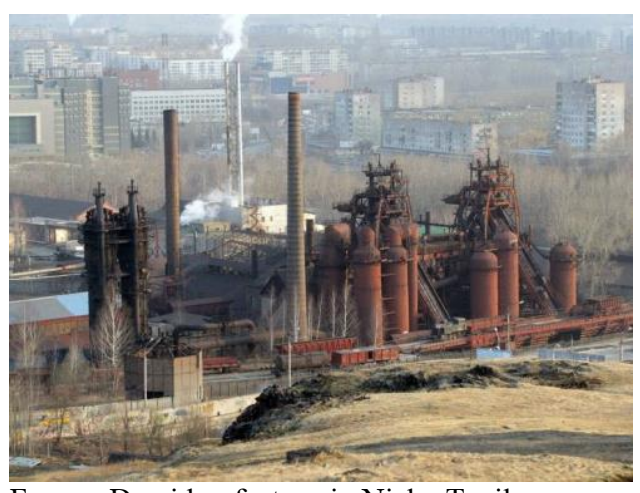

Former Demidov factory in Nizhy Tagil

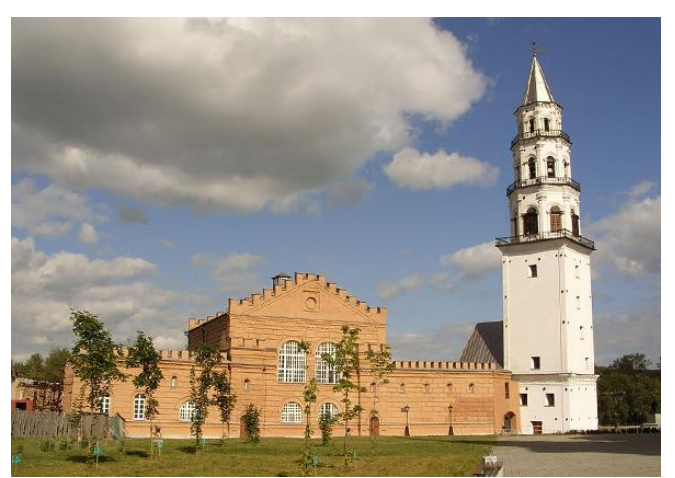

The restored Nevyansk factory

Fig. 5. Pictures of the former factories museum complexes in the Ural Region

Implementing the concept of revitalizing would allow solving the issues listed above and achieving some social and economic goals.

Ecological - transforming the abandoned and spoiled territories into ecologically clean and safe areas.

Social:

- improving the status of territories and transforming them into high-demand areas among the population;

- initiating the possibility to educate the youth about the traditions which were created in the particular historical time-periods;

- informing the local population and tourists on the history of establishing manufacture processes in Russia.

Economic:

- establishing a new economic branch - tourism (industrial tourism) which is connected with the creation (construction) and development of the touristic infrastructure and service spheres as well as small businesses;

- creating new work places;

- increasing the cadastral and stock market price of the land property and immovable property.

\subsection{Discussion}

The proposed mining cities classification is certainly debatable. Traditionally, old towns are considered to be those which are approximately a 1000 years old: the cities of the Golden Rich of Russia, Kazan, etc., as well as St-Petersburg, Odessa, Ekaterinburg, the cities with a 300-years history; they fall under the group of average age cities. Considering that the development of the Middle Urals began 300-350 years ago, all cities, which were established in the 18 th century, can be classified as old. 
The proposed classification of the historical sites is based on the existing land management in the Ural mining cities.

The presented concept of revitalizing these sites is different from the options of restoring the manufacturing sites of such cities as Vienna, Moscow, St-Petersburg, Volgograd, Ekaterinburg, etc. The largest cities have a range of advantages:

- they have a more prestigious status and they are financially more prosperous;

- factories requiring renovation predominantly belong to the category of monumental buildings;

- manufacturing sites which are located in the areas adjacent to the central regions and not on the remote urban periphery;

- the architectural objects do not possess the same historic value as the Demidov heritage.

Meanwhile, the option of establishing the Duisburg-Nord landscape park in Duisburg can be used as a model example.

The main goal of the proposed concept is to preserve the historical heritage and create a large-scale museum complex.

Considering the fact that mining monocities are deprived of their urban planning companies, establishing such spheres as tourism would undoubtedly increase the economic potential of the municipal areas; however, it would also require particular sponsorship. The main source of financing should be the government and the existing Ural manufacturing facilities. The first source of financing is justified by the fact that the Ural Region has provided a great deal of useful resources and conveniences for the country, beginning from the times of Peter the First, and the Ural Region deserves to be provided with moral and financial support.

\section{Conclusion}

The presented research provides an analysis of a large scope of information sources, maps, pictures and other materials.

The main results of the study are:

1) a proposed classification of the Ural mining cities;

2) a proposed classification of the historical sites located in old mining cities;

3) a detection and statement of the existing problems in terms of land management, as well as social, ecological and economic problems existing in the old mining cities of the Sverdlovsk Region;

4) a suggestion on the revitalization for improving the quality of urban environment and reviving the historical manufacturing sites, thus, solving the ecological, social and economic problems.

The presented article is a follow-up research and a set of suggestions on the revitalization of the mining territories of the Ural Region. New mining cities also face a large scope of issues connected with the negative impact caused by the mining factories. The Ural mining carriers serve as a prominent example of this. On the one hand, they are unique mining monuments of the Ural Region, on the other hand, the abandoned and polluted territories worsen the ecological situation in the region and lead to an irrational land exploitation of the residential areas and nearby territories. Land recultivation, which is guided by law on the natural resources deposits, does not help solve the problem of the restoration. Thus, the issue of renovating such territories still remains unsolved and requires a detailed study. 


\section{References}

1. M. Kolchina, V. Konovalov, N. Kolchina, E3S Web of Conferences, 135, 04015 (2019)

2. Revitalization (urban studies) URL: ru.wikipedia.org/wiki/

3. D.S. Shalina, N.R. Stepanova, Fundamental Research, 12-2, 285-289 (2019)

4. E.N. Abduramanova, Scientific Youth Forum: technical and mathematical sciences: an online journal of the 31st International Student Scientific Research Conference Proceedings, 2(31)

5. Revitalization of territories URL: https://asninfo.ru/magazines/html-version/786$\mathrm{spb} / 16993$-revitalizatsiya-territorii.

6. Revitalization of manufacturing factories or the second life of a factory URL: http://trendclub.ru/blogs/futurodrom/8327

7. S.V. Kornienko, Energy conservation, 6, 14-23 (2019)

8. International Scientific Youth Conference "The Construction Science" proceedings, 350 - 353 (Vladimir: the Vladimir State University Publishing House, January 20-23, 2010)

9. J. Kretschmann, S. Brüggerhoff, Mining Heritage: future-oriented values of Germany, Done For Good-problems of postmining. An anthology based on the proceedings of the Scientific Research Mining Institute, 48-49 (TH Georg Agricola University. Bochum, 2016)

10. J. Kretschmann, C. Melchers, Done for good - challenges of post-mining, 173 (TH Georg Agricola University, Bochum, 2016).

11. V.E. Konovalov, A.I. Semyachkov, V.A. Pochechun, IOP Conf. Series: Materials Science and Engineering, 451, 012208 (2018)

12. The Demidov factories in the Urals URL: https://TripToTheUrals.ru demidovskiezavodi-na-urale.

13. Industrial heritage preservation: international experience and problematic spheres in Russia, International conference proceedings (Ekaterinburg, 1994)

14. The National Mining Park of the Middle Urals: zoning, mining sites, architectural, historical and cultural heritage and museum construction, 168 (Ekaterinburg, 2000)

15. Monuments of industrial heritage in the Urals URL: https://metalspace.ru 